Tersedia Online di http://journal.unismuh.ac.id/index.php/otoritas

Otoritas : Jurnal Ilmu Pemerintahan, 7 (1), April 2017, 28-36

\title{
Integritas Perilaku Kepemimpinan Publik Walikota Bandung
}

\author{
Raykevin Bagus Julian Maramis*), Kristian Widya Wicaksono \\ Program Studi Ilmu Administrasi Publik Fakultas Ilmu Sosial dan Ilmu Politik, Universitas Katolik \\ Parahyangan, Jalan Ciumbuleuit No.94, Bandung, Jawa Barat, Indonesia
}

Diterima: 06 Februari 2017; Disetujui: 25 Maret 2017; Dipublikasikan: 14 April 2017

\begin{abstract}
Some of the achievements that Bandung City had today, is a positive value for the performance of Bandung City Government. Public leadership behavior of Bandung City Mayor becomes one of a several factors that increasing the performance of Bandung City Government. The purpose of this study is to discover the tendency of public leadership behaviours of Bandung City Mayor based on five dimensions namely: accountability leadership, lawfulness leadership, ethical leadership, political loyal leadership, dan network governance leadership. The method of this research is a quantitative descriptive study, by using data collection techniques such as questionnaires from 30 respondents and interviews. The results of this study shows that the tendency of public leadership behavior of the mayor of Bandung City is inclined to the lawfulness leadership with a good category. This evidence comes from the behavior of the public leadership of Bandung City Mayor which always emphasize every employee to always obey and properly follow the rules and regulations that has been established.
\end{abstract}

Keywords: Leadership; Public Leadership; Public Leadership Behaviours

\begin{abstract}
Abstrak
Beberapa prestasi yang telah diraih oleh Kota Bandung di masa kepemimpinan Walikota Bandung saat ini, merupakan suatu nilai positif bagi kinerja Pemerintah Kota Bandung. Perilaku kepemimpinan publik dari Walikota Bandung menjadi salah satu faktor peningkatan kinerja dari Pemerintah Kota Bandung. Tujuan dari penelitian ini adalah ingin mengetahui kecenderungan perilaku kepemimpinan publik dari Walikota Bandung dilihat dari lima dimensi yaitu: accountability leadership, lawfulness leadership, ethical leadership, political loyal leadership, dan network governance leadership. Pada penelitian ini, peneliti menggunakan jenis penelitian kuantitatif deskriptif, menggunakan teknik pengumpulan data berupa kuesioner dan wawancara. Hasil dari penelitian ini menunjukan bahwa kecenderungan perilaku kepemimpinan publik dari Walikota Bandung adalah cenderung pada lawfulness leadership dengan kategori yang baik. Hal ini terlihat dari perilaku kepemimpinan publik dari Walikota Bandung yang selalu menekankan setiap pegawainya untuk selalu menaati dan secara benar mengikuti aturan dan regulasi yang telah ditetapkan.
\end{abstract}

Kata kunci : Kepemimpinan; Kepemimpinan Publik; Perilaku Kepemimpinan Publik

Cara Penulisan Sitasi: Maramis, R. B. J., \& Wicaksono, K. W. (2017). Integritas Kepemimpinan Publik Walikota Bandung. Otoritas : Jurnal Ilmu Pemerintahan, 7(1), 28-36.

*)Penulis Korespondensi.

E-Mail : maramiskevin@gmail.com

Copyright (C) 2017, Otoritas : Jurnal Ilmu Pemerintahan, p-ISSN: 2088-3706, e-ISSN: 2502-9320 
Tersedia Online di http://journal.unismuh.ac.id/index.php/otoritas

Otoritas : Jurnal Ilmu Pemerintahan, 7 (1), April 2017, 29

\section{Pendahuluan}

Mengingat bahwa bentuk dari Negara Indonesia adalah Negara Kepulauan, tidak memungkinkan bahwa pemerintahan dijalankan secara sentralistik. Ketidakmampuan pemerintah dalam mencakup seluruh daerah yang ada di Indonesia menjadi salah satu penyebab Indonesia menggunakan sistem desentralisasi dan pemerintahan daerah.

Dalam menjalankan desentralisasi peran dari seorang kepala daerah menjadi hal vital dalam mencapai tujuan tersebut. Banyak tantangan dan hambatan yang akan dihadapi. Apalagi dalam konteks Indonesia yang bergeliat dengan tuntutan reformasi, good governance tampil sebagai model transplantatif baru yang diyakini mampu mengobati birokrasi politik yang dinilai sarat korupsi, suap, dan penyalahgunaan kekuasan (Prianto, 2011).

Pemimpin daerah memiliki kewenangan sendiri untuk mengurus daerahnya. Maka dari itu tanggung jawab dan kesempatan memberi pengabdian terbaik dipegang oleh seorang pemimpin, karena pemimpin inilah yang nantinya akan membawa daerahnya untuk mencapai tujuannya berdasarkan visi dan misi dari pemimpin tersebut. Kepemimpinan membutuhkan suatu kemampuan yang lebih tinggi. Seorang pemimpin akan menentukan ke mana arah suatu organisasi baik arah tujuan internal maupun eksternal.

Kota Bandung merupakan salah satu kota yang menerapkan pemerintahan daerah. Walikota Bandung yaitu Ridwan Kamil memiliki tanggung jawab untuk mensejahterakan masyarakatnya. Sebagai seorang Walikota Bandung tentunya, dibutuhkan kemampuan untuk memimpin. Pemimpin dapat dikatakan sebuah tokoh sentral yang dapat mempengaruhi lingkungannya. Kepemimpinan dari pemimpin daerah tersebut dapat mempengaruhi keberhasilan ataupun kegagalan dari daerahnya untuk men- capai tujuannya. Dalam pengertian umum, (Effendy, 1977) kepemimpinan menunjukan proses kegiatan seseorang dalam memimpin, membimbing, mempangaruhi, atau mengontrol pikiran, perasaan atau tingkah laku orang lain.

Kepemimpinan dibutuhkan manusia karena adanya keterbatasan keterbatasan tertentu pada diri manusia. Dari sinilah timbul kebutuhan untuk memimpin dan dipimpin. Kepemimpinan didefinisikan ke dalam ciri-ciri individual, kebiasan, cara mempengaruhi orang lain, interaksi, kedudukan dalam oragnisasi dan persepsi mengenai pengaruh yang sah. Pemimpin juga menyelaraskan fungsi dari organisasi dengan setiap resiko resiko yang ada.

Terkait dengan penyelenggaraan pemerintahan, birokrasi sebagai ujung tombak pelaksana pelayanan publik mencakup berbagai program-program pembangunan dan kebijaksanaan pemerintah (Usman, 2011). Sehingga perlu mememperkuat kepemimpinan agar proses birokrasi sebagai gambaran keberhasilan seorang pemimpin.

Pemimpin juga dinilai harus memiliki wawasan dan kemampuan dalam menyusun serta bersama-sama mengimplementasikan langkah kerja dan strategi untuk menetapkan tujuan organisasi. Mendefinisikan kepemimpinan merupakan suatu masalah yang cukup kompleks. Namun, bagi Safaria (2004) perkembangan ilmu saat ini telah membawa banyak kemajuan sehingga pemahaman tentang kepemimpinan menjadi lebih sistematis dan objektif.

Salah satu hal yang seringkali dapat mempengaruhi kepemimpinan publik adalah perilaku kepemimpinan dari pemimpinnya itu sendiri. Maka perlu integritas yang jelas. Integritas merupakan hal sangat penting dimiliki oleh seorang pemimpin. Ketika seorang pemimpin tidak memiliki integritas maka cepat atau lambat akan hancurlah kelompok atau organisasi yang dipimpinnya itu (Gea, 2014).

Perilaku kepemimpinan dari Wali-

Copyright (C) 2017, Otoritas : Jurnal Ilmu Pemerintahan, p-ISSN: 2088-3706, e-ISSN: 2502-9320 
Tersedia Online di http://journal.unismuh.ac.id/index.php/otoritas

Otoritas : Jurnal Ilmu Pemerintahan, 7 (1), April 2017, 30

kota Bandung ini menjadi suatu hal yang menarik. Setidaknya sudah cukup banyak penghargaan yang telah diraih oleh Pemerintah Kota Bandung dimasa kepemimpinan Ridwan Kamil, selaku Walikota Bandung.

Perilaku kepemimpinan adalah perilaku khusus/pribadi para pemimpin terkait dengan tugas dan perannya sebagai seorang pemimpin. Perilaku kepemimpinan dipahami sebagai suatu kepribadian seorang pemimpin yang diwujudkan dalam aktivitas kepemimpinannya dalam kaitannya dengan mengelola tugas dan hubungan dengan bawahan/pegawai untuk mencapai tujuan organisasi. Perilaku kepemimpinan adalah perilaku atau cara yang dipilih dan dipergunakan pemimpin dalam mempengaruhi pikiran, perasaan, sikap dan perilaku para anggota organisasi bawahannya.

Menurut Tummers dan Knies (2014) terdapat 5 dimensi kunci dalam melihat perilaku yang dimiliki oleh seorang pemimpinan publik yaitu, $A c$ countibility Leadership, Lawfullness Leadership, Ethical Leadership, Political Loyal Leadership, Network Governance Leadership. Maka dari itulah penulis bermaksud untuk menganalisa perilaku kepemimpinan dari Walikota Bandung dilihat dari kecenderungannya berdasarkan 5 dimensi dari Public Leadership Behaviours oleh Tummers dan Knies.

\section{Metode Penelitian}

Penelitian ini mengunakan pendekatan kuantitatif dengan metode deskriptif. (Silalahi, 2009) Hal ini bertujuan untuk menggambarkan secara tepat sifat-sifat suatu individu, keadaan, gejala, atau kelompok tertentu, atau untuk menentukan frekuensi atau penyebaran suatu gejala atau frekuensi adanya hubungan tertentu antara suatu gejala dan gejala lain dalam masyarakat.

Kemudian teknik sampling yang digunakan adalah teknik pengambilan sampel nonprobabilitas dengan menggunakan sampling jenuh. Peneliti menggunakan sampling ini karena responden yang dipilih merupakan kepala kepala SKPD yang berkoordinasi dan berhubungan secara langsung dengan Walikota Bandung. Penetunan responden secara sampling ini berdasarkan struktur organisasi Pemerintahan Kota Bandung yang menggambarkan alur - alur koordinasi langsung kepada Walikota Bandung

Instrumen yang dipergunakan dalam penelitian ini adalah kuisioner, pertanyaan yang diberikan berdasarkan dari indikator dimensi, studi literature, dan dokumentasi. Dalam kuisioner ini setiap pertanyaan yang diberikan telah disertai dengan alternatif jawaban. Responden tidak diperbolehkan memberikan jawabannya diluar dari alternatif jawaban yang sudah diberikan. Dalam penelitian ini kuisioner ditujukan ntuk mengumpulkan data tentang kecenderungan perilaku Walikota Bandung pada masa jabatannya. Kuisioner yang digunakan adalah kuisioner tertutup.

Dalam penelitian ini, skala yang digunakan adalah skala ordinal. (Silalahi, 2009) Skala ordinal berarti mengurut kategori respon dari tingkat terendah ke tingkat tertinggi menurut atribut dari suatu urutan atau orde tertentu. Skala yang akan dipergunakan dalam penelitian ini adalah skala ordinal. Teknik pengumpulan skala yang digunakan dalam penelitian ini adalah Skala Likert. Skala Likert memperlihatkan bagaimana tanggapan atau respon dari responden terhadap pertanyaan yang diberikan. Dengan menggunakan pengukuran ini maka akan ditetapkan beberapa alternatif jawaban dan setiap jawaban akan dihubungkan dengan skor nilai untuk masingmasing pertanyaan.

Untuk memudahkan penilaian rata rata dari setiap dimensi ini maka dibuat interval (Sudjana, 2005). Untuk menentukan panjang kelas interval digunakan rumus sebagaimana pada tabel 1 . 
Tersedia Online di http://journal.unismuh.ac.id/index.php/otoritas

Otoritas : Jurnal Ilmu Pemerintahan, 7 (1), April 2017, 31

Tabel 1. Skala Pengukuran

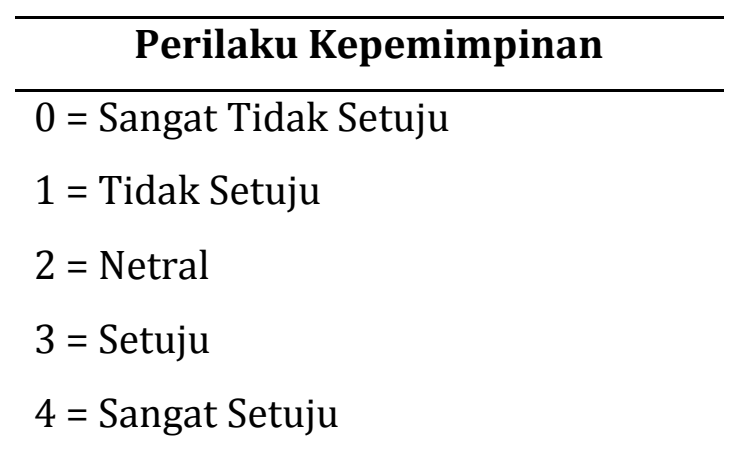

Dimana :

- P = Panjang Kelas Interval

- Rentang $=$ Selisih kelas terbesar - kelas terkecil

- Banyak kelas = 5

Berdasarkan rumus di atas, maka panjang kelas interval adalah :

$$
\mathrm{P}=\frac{\frac{5-1}{5}}{5}=0,8
$$

\begin{tabular}{cc}
\hline Interval & $\begin{array}{c}\text { Alternatif Jawaban } \\
\text { Perilaku } \\
\text { Kepemimpinan } \\
\text { Publik }\end{array}$ \\
\hline $1,00-1,79$ & Sangat Tidak Baik \\
$1,80-2,59$ & Tidak Baik \\
$2,60-3,39$ & Cukup Baik \\
$3,40-4,19$ & Baik \\
$4,20-5,00$ & Sangat Baik \\
\hline
\end{tabular}

Tabel 2. Interval dan Kategori Dimensi

Untuk menguji reliabilitas alat ukur peneliti menggunakan metode korelasi belah dua (Sudjana, 2005). Metode ini digunakan untuk menguji konsistensi keandalan alat pengukur dengan menggunakan satu alat pengukur untuk mengukur objek yang sama pada waktu

yang sama. Rumus yang digunakan adalah rumus Spearman-Brown. Rumusnya adalah :

$$
\frac{n r_{t t}}{1(n-1) r_{t t}}
$$

Keterangan :

$\mathrm{n}=$ Rasio dari jumlah item-item

pertanyaan yang diuji

$r_{t t}=$ Keandalan yang telah diperoleh

Pedoman koefisien reliabilitas yang digunakan dalam penelitian ini adalah:

$0,90-1,00$ : luar biasa bagus (excelent)

$0,85-0,89$ : sangat bagus (very good)

$0,80-0,84$ : bagus (good)

$0,70-0,70$ : cukup (fair)

$<0,70$ : kurang (poor)

Pertanyaan yang berada pada rentang 0,70 - 1,00 dapat diandalakan dan reliabel

Pada uji validitas, Terdapat rumus yang digunakan untuk menguji korelasi rank spearman. Cara mengukur validitas kuesioner adalah menghitung korelasi antar skor item pada masing-masing pernyataan dengan skor total. Rumusnya adalah:

$$
r n=\frac{n r n}{1(n-1) r n}
$$

Keterangan:

n: Rasio dari jumlah item-item pernyataan yang diuji

rn : Keandalan yang telah diperoleh

Koefisien korelasi validitas yang digunakan dalam penelitian ini adalah:

- Jika r hitung > table $(0,3061)$ bernilai positif, maka dinyatakan valid.

- Jika $r$ hitung < table $(0,3061)$ bernilai positif, maka dinyatakan tidak valid.

- Jika $r$ hitung > table $(0,3061)$ bernilai negatif, maka dinyatakan tidak valid.

- Jika $r$ hitung < table $(0,3061)$ bernilai negatif, maka dinyatakan tidak valid.

Pernyataan akan dianggap valid apabila koefisien korelasi lebih besar dari 0,3061. 
Tersedia Online di http://journal.unismuh.ac.id/index.php/otoritas

Otoritas : Jurnal Ilmu Pemerintahan, 7 (1), April 2017, 32

Tabel 3. Hasil Uji Reliabilitas Variabel

\begin{tabular}{lccc}
\hline \multicolumn{1}{c}{ Dimensi } & $\begin{array}{c}\text { Koefesien } \\
\text { Reliabilitas }\end{array}$ & Titik Kritis & Kesimpulan \\
\hline Accountibility & 0,792 & 0,700 & Reliabel \\
Lawfullnes & 0,830 & 0,700 & Reliabel \\
Ethical & 0,846 & 0,700 & Reliabel \\
Political & 0,865 & 0,700 & Reliabel \\
Network & 0,810 & 0,700 & Reliabel \\
\hline
\end{tabular}

Untuk menganalisis data yang telah terkumpul dari hasil penelitian yang bersifat kuantitatif ini, maka penulis menggunakan analisis statistik deskriptif (Sugiyono, 2007). Analisis statistik deskriptif bertujuan untuk memberikan deskripsi mengenai subjek penelitian berdasarkan data variabel yang diperoleh dan kelompok subjek yang diteliti (Sugiyono, 2007). Statistik deskriptif merupakan prosedur-prosedur dalam mengorganisasikan dan penyajian informasi dalam satu bentuk yang dapat digunakan dan dapat dikomunikasikan atau dapat dimengerti.

\section{Hasil dan Pembahasan}

Pada bagian ini akan disajikan hasil penelitian serta pembahasan yang telah diperoleh melalui penyebaran kuesioner pada responden sebagai sumber data utama dalam penelitian ini, selain upaya perolehan data melalui observasi, wawancara dan studi pustaka untuk melengkapi data utama. Penelitian ini memiliki tujuan untuk mengetahui Kecenderungan Perilaku Kepemimpinan Publik berdasarkan Five Dimensions of Public Leadership Behaviours.

Pertama adalah Accountibility Leadership yaitu perilaku kepemimpinan dimana pemimpin mendorong timnya untuk mendiskusikan setiap tindakan yang mereka lakukan untuk masyarakat, dan dari sudut pandang tim atau pegawai, akan melihat pemimpin sebagai sosok orang yang bertanggung jawab akan timnya dan tindakan yang mereka lakukan.

Berdasarkan hasil penelitian terhadap dimensi Accountibility yang dilakukan terhadap Walikota Bandung ini termasuk dalam kategori cukup baik. Hal ini terlihat dari skor responden pada setiap pernyataan yang relatif cukup baik. Responden dalam penelitian ini merasa cukup setuju bahwa Walikota Bandung mendorong setiap pegawainya baik itu staf maupun SKPDnya untuk menjelaskan alasan dan tujuan dari setiap keputusan dan tindakan yang dilakukan kepada masyarakat Kota Bandung. Walikota Bandung juga terkadang mendorong setiap pegawainya untuk menginformasikan cara bekerja dari pegawainya, menjelaskan perilaku pegawainya, meyakinkan pegawainya kepada masyarakat bahwa mereka sangat terbuka kepada masyarakat, dan mendorong pegawainya agar dapat menjelskan tujuan dari tindakan dan keputusan yang diambil kepada masyarakat. Responden juga setuju bahwa Walikota Bandung selalu menekankan kepada setiap pegawainya baik itu staf maupun SKPDnya bahwa menjawab pertanyaan publik merupakan suatu hal yang sangat penting dan tidak dapat dikesampingkan. Salah satu contoh yang dapat dilihat adalah Walikota Bandung melalui media sosial internet dan media cetak selalu memaparkan program-program yang akan dilaksanakan dan dampak dampak dari program yang telah terlaksana. Melalui 
Tersedia Online di http://journal.unismuh.ac.id/index.php/otoritas

Otoritas : Jurnal Ilmu Pemerintahan, 7 (1), April 2017, 33

media sosial ini masyarakat bisa mengetahui langsung program yang sedang dilaksanakan dan dapat memberikan aspirasinya.

Kedua, Lawfulness Leadership yaitu kepemimpinan dengan sikap dan sifat yang senantiasa memberi contoh dan mengajak pegawai atau karyawannya dalam menaati hukum atau peraturan yang telah diatur. Berdasarkan hasil penelitian dan data yang telah diperoleh untuk dimensi lawfullness yang dilakukan terhadap Walikota Bandung, termasuk ke dalam kategori baik. Hal ini diperkuat dengan tanggapan responden terhadap setiap pernyataan cenderung setuju bahwa Walikota Bandung seringkali memastikan pegawainya untuk taat pada setiap peraturan dan regulasi yang sudah ada dan menekankan pegawainya untuk menerapkan kebijakan yang telah dibuat dengan baik dan benar. Walikota Bandung juga terkadang memberikan pengertian kepada pegawainya untuk dengan baik mengikuti aturan yang ada, serta menjelaskan kepada pegawainya bahwa sangat penting untuk mengikuti aturan yang sudah ada.

Keabsahan secara hukum menjadi hal yang penting bagi aparatu daerah dalam melaksanakan setiap tugas dan kewajiban yang dimilikinya. Pada masa kepemimpinan Walikota Bandung saat ini, birokrasi yang ada telah dipangkas agar masyarakat dapat lebih mudah untuk menggunakan layanan telah disediakan. Untuk itu perlu kesiapan yang baik bagi setiap pegawainya. Sebagai pelayan publik, tentunya telah diatur secara hukum untuk bertugas sebagaimana mestinya. Peraturan yang ada dibuat untuk mempermudah serta mengontrol kinerja dari setiap pegawainya agar tetap dapat bekerja dengan optimal bagi masyarakat.

Ketiga, Ethical Leadership sebagai kepemimpinan yang senantiasa mendorong tim dalam organisasinya untuk berperilaku normatif sesuai yang belum tentu ditetapkan dalam peraturan. Pera- turan peraturan yang ada tidak seluruhnya mengikat hal hal yang normatif, maka dari itu terdapat perilaku perilaku organisasi yang secara normatif perlu diawasi agar tetap sesuai dengan peraturan yang ada.

Dimensi ketiga yang menjadi alat ukur penelitian dalam penelitian ini adalah dimensi ethical atau etika. Kepemimpinan beretika atau ethical Leadership mengacu pada perilaku seorang pemimpin yang mengawasi hal hal yang bersifat normatif yang dilakukan oleh organisasinya. Tidak seluruh peraturan yang ada mengatur hal-hal yang bersifat normatif, maka dari itu seorang pemimpin perlu mengawasi organisasinya untuk secara normatif sesuai. Hal normatif dalam hal ini dikatakan sebagai kode etik yang berlaku di dalam organisasi.

Dari hasil penelitian terhadap dimensi ethical yang dilakukan terhadap Walikota Bandung termasuk ke dalam kategori cukup baik. Walikota Bandung terkadang menjelaskan kepada pegawainya mengenai kode etik yang digunakan dalam organisasinya, menjelaskan harapan beliau terhadap organisasinya sehubungan dengan integritas, menjelaskan maksud tujuan dari integritas kepada organisasinya, mendorong pegawainya untuk berdiskusi bilamana terjadi permasalahan internal yang dapat berdampak buruk bagi organisasinya.

Berdasarkan penelitian ini juga melalui data yang diperoleh, Walikota Bandung seringkali memastikan setiap pegawainya untuk mengikuti kode etik yang telah berlaku dalam organisasinya, serta menjelaskan konsekuensi yangakan diterima bila melanggar kode etik yang sudah ada, dan seringkali mengapresisasi pegawainya atas kinerja yang dilakukan oleh pegawainya.

Keempat, Political Loyal Leadership yang menitikberatkan pada supervisor yang mendorong pegawainya untuk bertindak sesuai dengan kepentingan politik meskipun beresiko bagi dirinya. Ini se- 
Tersedia Online di http://journal.unismuh.ac.id/index.php/otoritas

Otoritas : Jurnal Ilmu Pemerintahan, 7 (1), April 2017, 34

bagai kepatuhan politik.

Berdasarkan hasil penelitian terhadap dimensi political yang dilakukan terhadap Walikota Bandung termasuk dalam kategori yang tidak baik dengan skor yang rendah pada setiap pernyataan. Responden pada penelitian ini tidak setuju bahwa Walikota Bandung mendorong pegawainya untuk mengimplementasikan keputusan politik yang akan melemahkan kinerja dari organisasinya, menyuruh pegawainya untuk selalu mendukung keputusan politik, menekankan pegawainya untuk tidak membahayakan hubungan relasi pimpinan politik, menyuruh pegawainya untuk mengimplementasikan keputusan politik yang bahkan akan menimbulkan pertanggungjawaban baru, dan mendorong pegawainya untuk selalu melindungi keputusan politik yang ada.

Pada dimensi ini skor yang telah didapat melalui alat ukur terhadap responden cenderung rendah dan berada pada kategori yang tidak baik. Sebagai seorang pemimpin publik tentunya memiiki tanggung jawab yang sangat besar atas setiap keputusan dan tindakantindakan yang diambil melalui program maupun kebijakan. Untuk itu orientasi yang tercipta adalah untuk masyarakat, karena setiap produk yang dibuat oleh pemerintah setidaknya akan berdampak baik maupun buruk bagi masyarakat dan organisasinya itu sendiri. Sebagai seorang Walikota tentunya kehati-hatian menjadi hal sangat penting dalam setiap pengambilan setiap pengambilan keputusan.

Kemudian yang terakhir adalah Network Governance Leadership yaitu cara untuk mendorong pegawai atau tim untuk secara aktif berhubungan dengan pemangku kepentingan diluar dari instansi atau organisasi mereka. Kemampuan membangun jaringan sangat diperlukan oleh pemimpin di era kekinian.

Berdasarkan hasil penelitian terhadap dimensi network yang dilakukan terhadap Walikota Bandung termasuk dalam kategori cukup baik.Walikota Ban- dung terkadang mendorong pegawainya untuk berinteraksi dengan organisasi lain, menekankan pegawainya untuk selalu berkomunikasi dengan pihak lainnya, Mendorong pegawainya untuk berinteraksi dengan organisasi lain, mendorong untuk berkomunikasi dengan pihak pihak lainnya, mendorong pegawainya untuk bekerja sama dengan organisasi lain agar tercipta koneksi baru, memberikan keleluasaan bagi pegawainya untuk membangun hubungan pekerjaan dengan organisasi lain, menghabiskan waktunya untuk mengurus hubungan hubungannya kepada organisasi lain atau pihak lain, mendorong pegawainya untuk lebih bekerja keras untuk menjaga dan membangun koneksi baru dengan pihak lain, mendorong pegawainya untuk terus terhubung dengan organisasi-organisasi lain.

Pada dimensi network ini perilaku kepemimpinan publik Walikota Bandung cenderung cukup dan berada dalam kategori cukup baik. Dimensi network mengacu pada sejauh mana Walikota menekankan kepada organisasinya untuk terus menjalin hubungan relasi dengan organisasi lain.

Sebagai seorang pemimpin publik, Walikota Bandung tentunya memiliki banyak sekali relasi yang dapat menguntungkan kinerja dari organisasinya. Membangun sebuah relasi dan koneksi merupakan suatu hal yang dan dapat mendukung kinerja dan menambah pengetahuan bagi pemimpin dan organisasinya agar dapat lebih baik. Namun dibutuhkan sebuah batasan bagi pemerintah dan relasinya, agar tidak terjadi penumpukan kepentingan. Sebagai seorang Walikota hal ini menjadi tugas yang cukup berat agar profesionalitas dari organisasi dan relasinya tetap terjaga dengan baik.

Akumulasi dari Berdasarkan hasil penelitian pada seluruh dimensi dari five dimensions of public leadership yang telah dilakukan terhadap Walikota Bandung 
Tersedia Online di http://journal.unismuh.ac.id/index.php/otoritas

Otoritas : Jurnal Ilmu Pemerintahan, 7 (1), April 2017, 35

menunjukan suatu kecenderungan perilaku kepemimpinan publik dari Walikota Bandung. Kecondongan dapat dilihat melalui tanggapan yang telah diberikan oleh responden dan melalui hasil olah data yang telah dilakukan.

Dari hasil penelitian ini kecenderungan perilaku kepemimpinan publik dari Walikota Bandung adalah pada dimensi lawfulness leadership. Hal ini terlihat tanggapan para responden serta hasil wawancara pada beberapa pegawai di beberapa SKPD Kota Bandung yang cenderung termasuk dalam kategori baik Perilaku kepemimpinan publik Walikota Bandung yang cederung kepada lawfulness leadership ini juga terlihat dari skor serta tanggapan responden yang cenderung baik.

Berdasarkan hasil penelitian ini, keseluruhan dimensi memang menunjukan skornya masing masing. Skor tertinggi terletak pada dimensi lawfulness leadership dan skor terendah terletak pada dimensi political loyal leadership. Hal ini menunjukan suatu kecenderung yang dapat dijadikan acuan sebagai dasar kesimpulan penelitian. Melalui hasil peneitian ini Walikota Bandung cenderung selalu menekankan kepada selruh pegawainya untuk selalu taat kepada regulasi dan peraturan yang sudah ada.

Sebagai seorang pemimpin publik yang juga menjadi sosok panutan dalam organisasinya tentunya untuk menyesuaikan diri dan menaati peraturan yang ada merupakan salah satu tanggung jawab yang besar. Perilaku kepemimpinan publik yang cenderung kepada lawfulness atau keabsahan secara hukum ini juga diterapkan pada masyarakat Kota Bandung. Seringkali Walikota Bandung melakukan sidak ke bangunan bangunan yang dirasa telah menyalah aturan. Contohnya beliau menyambangin bangunan bangunan dan menyegel bangunan yang IMB tidak sesuai dengan peraturan IMB di Kota Bandung. Kemudian penertiban bagi masyarakat pengguna kendaraan bermo- tor yang menggunakan knalpot bising, kemudian larangan penggunaan Styrofoam bagi para pedagang untuk mengurangi sampah styrofoam yang cukup tinggi di Kota Bandung.

Di dalam lingkungan organisasinya Walikota Bandung menekankan pegawainya untuk dengan benar mengikuti peraturan yang ada. Sebagai seorang pelayan publik mereka memiliki tugas untuk melayani masyarakat, untuk itu masyarakat harus menilai baik kinerja dari para pelayanan publik, salah satunya adalah bekerja sesuai regulasi yang telah diteapkan agar tercipta profesionalitas dalam bekerja. Peraturan yang telah dibuat di Kota Bandung pada dasarnyaditujukan untuk mengatur dan memperjelas cara bekerja yang akan diterapkan oleh organisasinya. Hal ini pun diharapkan dapat meningkatkan kinerja dari Walikota Bandung dan setiap pegawainya.

\section{Kesimpulan}

Perilaku kepemimpinan dari Walikota Bandung pada setiap dimensi dapat dikatakan cukup baik terlihat dari kategori yang dicapai dalam setiap dimensi memenuhi terpenuhi pada kategori cukup baik dan baik. Tidak terdapat skor yang sangat buruk pada setiap dimensi baik itu pada dimensi acoountibility hingga network governance. Seluruhnya memenuhi kategori cukup baik dan baik. Berdasarkan hasil penelitian ini setiap dimensi memiliki ukurannya masing masing yang dapat menentukan kecenderungan perilaku kepemimpinan publik dari Walikota Bandung.

Berdasarkan hasil ini perilaku kepemimpinan publik berdasarkan Five Dimensions of Public Leadership Behaviours dari Walikota Bandung adalah Lawfulness Leadership atau kepemimpinan yang lebih menekankan kepada hukum yang berlaku. Walikota Bandung menekankan pegawainya untuk menerapkan kebijakan pemerintah dengan benar agar masyarakat dapat merasakan dam- 
Tersedia Online di http://journal.unismuh.ac.id/index.php/otoritas

Otoritas : Jurnal Ilmu Pemerintahan, 7 (1), April 2017, 36

pak dari kebijakan yang telah diimplementasikan dengan baik. Hal ini dengan tujuan untuk mencapai profesionalitas kerja serta menunjang kinerja dari Walikota Bandung dan organisasinya.

\section{Ucapan Terima Kasih}

Atas selesainya penelitian hingga terbitnya artikel pada Otoritas : Jurnal Ilmu Pemerintahan, saya tidak dapat melepaskan diri dari budi baik Pimpinan dan Dosen pada Program Studi Ilmu Administrasi Publik Universitas Katolik Parahyangan, Bandung.

\section{Daftar Pustaka}

Effendy, O. U. (1977). Kepemimpinan dan Komunikasi. Bandung: Almuni.

Gea, A. A. (2014). Integritas Personal dan Kepemimpinan Etis. Humaniora, 5 (2), 950-959.

Prianto, A. L. (2011). Good Governance dan Formasi Kebijakan Publik Neo-Liberal. Otoritas: Jurnal Ilmu Pemerintahan, 1(1).

Safaria, T. (2004). Kepemimpinan. Yogyakarta: Graha Ilmu.
Silalahi, U. (2009). Metode Penelitian Sosial. Bandung: Refika Aditama.

Sudjana, S. (2005). Metode Penelitian Sosial. Bandung: Tarsito.

Sugiyono, S. (2007). Metode Penelitian Kualitatif Kuantitatif dan $R \& D$. Bandung: Alfabeta.

Tummers, L., \& Knies, E. (2014). The public leadership questionnaire: The development and validation of five dimensions of public leadership behaviors. CA: Sage Publications.

Usman, J. (2011). Manajemen Birokrasi Profesional dalam Meningkatkan Pelayanan Publik. Otoritas: Jurnal Ilmu Pemerintahan, 1(2). 